\title{
American Red Cross
}

Debora J. Gilliard (E-mail: gilliard@mscd.edu), Metropolitan State College of Denver, USA

Rajendra Khandekar (E-mail: khandekr@mscd.edu), Metropolitan State College of Denver, USA

\begin{abstract}
The American Red Cross has been plagued with problems over the past two years from an antitrust lawsuit, repercussions from the distributions of funds from the Liberty Fund to the survivors of the World Trade Center disaster, problems with donated blood, a negative report from the Better Business Bureau, and a negative news report on CBS's '60 Minutes'. This case study looks at the history of the Red Cross, provides information about the services provided by the organization, discusses the problems the American Red Cross has encountered over the past 3 years, and introduces Marsha Evans who took the position of CEO in August 2002.
\end{abstract}

\section{Introduction}

C Marsha 'Marty' Johnson Evans took the helm of the American Red Cross on August 5, 2002, she was faced with the challenge of restoring the public's faith in the organization. During the past 24 months, there has been a barrage of negative publicity regarding the American Red Cross. In June 2000, workers at the American Red Cross went on strike. The organization was hit by a lawsuit filed by HemaCare Corp. and Coral Blood Services in January 2001. The plaintiffs alleged that the American Red Cross engaged in unfair trade practices in the pricing of blood. The Better Business Bureau made false public statements about the ability of American Red Cross to meet their standards for charitable solicitations. Then on September 11, 2001, Americans watched in horror as terrorists flew two planes into the World Trade Center buildings. In the aftermath of this tragedy, donations poured into the American Red Cross, and a special fund - the Liberty Disaster Relief Fund - was established by the then American Red Cross President Bernadine Healy. When it was announced that not all donations would be used for victims of the 9/11 disaster, there was a huge public outcry from donors. Dr. Bernadine Healy was forced to retire, and interim CEO Harold Decker announced that all donations to the Liberty Disaster Relief Fund would be used in the organization's 9/11 relief efforts. Finally, on March 10, 2002, 60 minutes, a CBS news show, ran a misleading and inaccurate story about the American Red Cross.

On June 27, 2002, Marsha Johnson Evans was named new CEO and President of the American Red Cross. At the time of this announcement, Evans stated:

"This is a time of great challenge for many charitable organizations including the American Red Cross. One the one hand, we need to motivate Americans to donate their time and their treasure, which is never easy, but always comes down to whether they trust an organization and believe in their work. On the other hand, we face a host of challenges including the need to better prepare this nation for disasters both natural and man-made; as well as the rigors of furnishing a safe and available blood supply with all the costs and complexity this involves. " [9]

\section{American Red Cross in 2002}

Henry Dunant set forth the idea of the Red Cross in 1859 when he saw wounded and dying soldiers on the battlefield in Solferino, Italy. He organized local people to bind the soldiers' wounds and to feed and care for them. Henry Dunant called for the creation of a national relief society and this pointed the way to the future Geneva Convention. In 1863, in Geneva, Switzerland, the International Red Cross was created with the purpose of providing nonpartisan care in times of war. The Red Cross emblem was adopted as a symbol of neutrality although today the Red Crescent is also a recognized symbol. Today the Red Cross incorporates the International Committee of the Red Cross and the International Federation of Red Cross and Red Crescent Societies as well as National Societies in 175 countries. The fundamental principles of the International Red Cross are listed in Exhibit 1 [3]. 
Clara Barton successfully organized the first lasting Red Cross Society in America in Washington D.C., on May 21, 1881. The American Red Cross provided services beyond those of the International Red Cross by providing disaster relief in additional to battlefield assistance. Clara Barton served as the organization's president through 1904 [3].

As stated in its 2000-01 Annual Report, "the American Red Cross is a humanitarian organization, led by volunteers, whose mission is to provide relief to victims of disasters and help people prevent, prepare for, and respond to emergencies". The Vision of the American Red Cross is "The American Red Cross... Always there... touching more lives, in new ways ... under the same trusted symbol". Since its founding, the American Red Cross has symbolized the nobility of the human spirit by representing service and goodwill across America. Its purpose, or intent, is to "prevent and relieve human suffering". Each year, March is proclaimed as American Red Cross month. To support the fundamental principles of the International Red Cross, the American Red Cross has adopted a set of values as shown in Figure 2.

A Board of Governors that formulates policy and delegates authority to its 1,000 local chapter volunteer boards of directors governs the American Red Cross. Decentralization allows the Red Cross to provide immediate, effective, and efficient assistance to those in need [6]. Annually, the American Red Cross helps victims of more than 63,000 natural and man-made disasters. The worst disaster ever dealt with by the American Red Cross was in 1900 when a hurricane killed an estimated 6,000 people in Galveston, Texas.

The American Red Cross helps victims through a wide range of services [1,2]:

- $\quad$ Armed Forces Emergency Services - Provides military families with emergency communication services, financial assistance, counseling, etc.

- $\quad$ Biomedical Services - Blood, tissue, and plasma services; research; and national testing labs. In FY2001 over 3.8 million volunteers donated in excess of 6 million pints of blood. The American Red Cross supplies 3,000 hospitals with about half of the blood used in the United States.

- $\quad$ Community Services - Help for the homeless, seniors, and youth; food and nutrition information; transportation, etc.

- $\quad$ Disaster Services - Educational services to prepare for disasters. Each year 83,000 volunteers help disaster victims by providing food, shelter, financial assistance, mental health counseling, etc.

- Health and Safety Services - Swimming and lifeguard classes, HIV/AIDS education, living well programs, etc. Over 12 million Americans each year take advantage of lifesaving courses offered by the Red Cross.

- International Services - Emergency disaster response, feeding programs, primary health care programs, Geneva Conventions, etc. The Red Cross is able to provide long-term aid and education to those in need. Also, Red Cross delegates help local citizens rebuild infrastructure, strengthen public health, and improve response time to local disasters.

- $\quad$ Nursing - Student nurses, Jane Delano Society, etc.

- $\quad$ Youth Involvement - helping kids, teens, and young adults.

- $\quad$ Volunteering - Recruiting and organizing volunteers

\section{Financial Overview}

In fiscal year 2000-01 the American Red Cross had operating revenues of $\$ 2.743$ billion. Total operating revenues for fiscal year 1999-00 were $\$ 2.517$ billion. Three main funding sources for the American Red Cross were [2]:

- $\quad$ Contributions: Fund raising efforts by the United Way \& Combined Federal Campaign, legacies, grants, other monetary and in-kind contributions

- $\quad$ Products and Services: Fees for products, materials, and courses; fees from collecting, testing, and distributing blood and tissue.

- Investment income and Other income (income from contracts to provide various programs and investment income from endowments and reserve funds): 

were [2]:

Total Operating Expenses for the 2000-01 fiscal year were $\$ 2.712$ billion and major expenses included

- Disaster Costs: Assistance to victims

- $\quad$ Funding Disaster Services: Expenses to solicit donations, administer funds, staff expenses at disaster sites, etc.

- $\quad$ Biomedical Services: Facility maintenance, expenses in blood, plasma, and tissue services.

Total operating expenses for the fiscal year 1999-2000 were $\$ 2.469$ billion.

\section{Technology}

Technology has helped the American Red Cross better coordinate its efforts among its 1,400 chapters and to expand its reach across America. In 2000, it launched "iGiveLife", a service that enables blood drive sponsors to use their intranets to recruit donors and allows hospital customers to order blood products online [1].

The Internet provides information about non-profit organizations and can provide 'click-to-donate' sites for those individuals who are willing to help out with contributions while they are online. These "click" sites appeal to a newer and often younger audience for the nonprofits. For Cindee Archer, online media manager for the American Red Cross in Washington D.C., the Internet serves as a vital source of information to the American Public and as a new way to collect donations. Archer stated, "The internet has definitely changed how the whole organization thinks. You feel this sense of urgency whenever there's a disaster --- you want that information up as quickly as you can get it" [16]. Archer worked on developing a website where visitors could enter a ZIP code and quickly find information. The website helps visitors locate local Red Cross shelters, find relatives in a disaster area, keep up with breaking news, and obtain information about donating and volunteering. Cindy Archer also believed that "More and more people are coming online - this isn't going to go away, it's only going to get more pervasive" [16]. However, there were costs associated with a website that many nonprofit groups did not realize. Russ Finkelstein, director of outreach at Action without Borders has stated "Some of them think this is going to be a kind of panacea for doing fund-raising, and it's not necessarily that" [16].

About 12 million Americans enroll in Red Cross courses each year. It is now possible to make these courses available online. The Red Cross has routinely published the latest public health information, and the use of new technology will make this information available online. Wireless communication allows the American Red Cross to make faster damage assessment at the scene. Communications network allows it to locate family members during crises more efficiently. In the near future, it may be possible for the American Red Cross to offer an online shopping network to generate additional resources [1].

\section{Strategic Alliances}

The American Red Cross has established a number of alliances with other organizations. It works with the World Health Organization to alleviate malnutrition, lack of pure water, and diarrhea in poor countries and to support primary health care. A donation to the World Hemophilia Foundation of plasma product is used to treat hemophilia. In 1999, the American Red Cross joined the Federal Emergency Management Agency for "TOPOFF", a nationwide disaster simulation to help prepare for acts of terrorism. As a result of recent research and development, Massachusetts General Hospital and the American Red Cross jointly own a patent for a protein associated with the underlying cause of Alzheimer's disease. In addition, the American Red Cross supplies over 3,000 hospitals with blood donations [1].

In February 2001,the American Red Cross teamed up with Coinstar, Inc, to collect Red Cross donations for disaster relief efforts. Consumers could drop loose change into the Coinstar machines located in local supermarkets. Coinstar machines were located within 2 miles of 130 million Americans. John Clizbe, Vice President of Disaster Services at the American Red Cross, indicated that "If every American near a Coinstar machine would donate a handful of change on their next supermarket visit, the Red Cross would be that much better prepared to respond to 
disaster immediately"(US Newswire). "You no longer need a credit card or checkbook to provide financial support to those in need," said Rich Stillman, $\mathrm{COO}$ of Coinstar. "If all Americans donate the change in their wallet or pocket, those handfuls will make a huge difference in our capacity to help others this year" [4].

Masterfoods USA, a Mars Incorporated Company, created a special package of Red, White, and Blue M\&M's specifically to benefit the Red Cross. The national campaign theme used for this promotion was "Taking Care of America Everyday." "Through appearances on television, radio and newspapers and creative displays in stores across the country, the new 'M\&Ms' captured the heart of America," stated Skip Seitz, senior vice president, American Red Cross Growth and Integrated Development [6]. One hundred percent of all profits from the sales of these M\&M's were donated to the American Red Cross Disaster Relief Fund. In January 2002, Masterfoods USA presented a check to the Red Cross in the amount of $\$ 3.5$ million.

In August 2001, the American Red Cross and the American Society of Association Executives signed an agreement in which the two organizations will share data regarding disasters, declarations, changes in legislation and will explore efforts in joint training exercises.

The ASAE provides the Red Cross with demographic information about associations and assistance with identifying organizations they wish to contact during times of need [10].

\section{Recent Problems}

Events during the past 2 years had already provided the American Red Cross with a number of challenges. In June 2000, Red Cross workers who collected blood donations and delivered them to hospitals went on strike after rejecting a contract offer by the American Red Cross. The workers were unhappy about long hours, frequent schedule changes, and increasing health benefit costs [15].

The Red Cross derived $60 \%$ of its revenues from the sale of blood [12]. In providing more than half the nation's blood, the Red Cross received annual sales of more than \$1.3 billion [17]. In January 2001, a California blood supplier filed an antitrust suit against the American Red Cross claiming the organization used its clout to eliminate competitors. HemaCare Corp. and Coral Blood Services allege the Red Cross has cost them more than $\$ 25$ million in lost business. They alleged that the American Red Cross prices some blood products (such as platelets) below production costs to drive out competitors while it charges higher prices for the same products in markets where there is no competition. In the lawsuit, the plaintiffs alleged the Red Cross violated Section 2 of the Sherman Antitrust Act, which prohibits monopolization. The lawsuit also charged tortuous interference, unfair trade practices, and unfair competition under the California Business and Professional Code [17]. William Nicely, HemaCare chief executive officer, stated, "We believe that's unfair and illegal. The Red Cross is a fine organization. We just want them to play by the rules that are reasonable and fair and compete on a level playing field"[17]. Blythe Kubina, a Red Cross spokeswoman said in a written statement, "We believe the American Red Cross has done nothing inappropriate regarding HemaCare's claims to unfair business practices and we were surprised by this lawsuit. We have been in full compliance with the law, and we will vigorously defend this lawsuit" [17].

After the terrorist attack on the World Trade Center on September 11, 2001, the American Red Cross rose to the challenge of providing the most extensive relief operation in its 120 -year history. In response to the September $11^{\text {th }}$ tragedy, the American Red Cross set up family assistance centers to provide counseling, childcare, food, financial assistance and other services to victims' families and other affected. Respite centers were set up in New York City, Somerset County, PA, and at the Pentagon to provide meals, sleeping quarters, and other items to relief workers and volunteers. Funds were used for travel, lodging, and meals for volunteers and staff working onsite. Financial assistance, counseling and transportation were provided to families of missing foreign nationals.

Millions of dollars, thousands of blood donations, and help from a myriad of volunteers contributed to the Red Cross' efforts to provide aid to survivors, victims families, and relief workers. Because of the large dollar 
amount of donations from the American people, the American Red Cross created the Liberty Disaster Relief Fund to be used exclusively to meet the needs of people directly affected by the September 11 tragedy.

Within 15 days of the September 11, 2001, attack, the Red Cross had collected \$202 million in donations. Deborah Goldburg, a Red Cross spokesperson stated, "Everything is happening at such a fast pace. Right now we are just trying to keep up with responses" [11]. Goldburg stated that the entire amount raised by the Red Cross since the disaster would go into the newly created Liberty Fund. She indicated that organization officials earmarked $\$ 100$ million from the fund to provide short-term financial assistance to families of victims. Bernadine Healy, M.D., the Red Cross' president and chief executive officer, said in a written statement, "What has taken place is extraordinary, and we must respond in an extraordinary way. The American Red Cross has a heavy burden - to live up to the inspiration and memory of those lost. It is with great humility and pride that we carry out this noble obligation," [11].

On October 12, 2001, the American Red Cross released a spending plan for the first $\$ 300$ million in the Liberty Fund. Less than $50 \%$ of the money raised was targeted for victims, their families, or rescue workers. The remainder was earmarked to help the Red Cross improve its own organization and expand into new programs of aid that may be needed in the event of future terrorist attacks [18]. This planned distribution of funds, based on Healy's policy of using donations for a "long period of uncertainty and recovery", caused a huge uproar [14]. The donors blasted CEO Dr. Bernadine Healy because they expected their donations to be helping September 11, 2001, disaster victims now. The Attorney General of New York State threatened legal action [12]. Healy finally responded with her announcement of retirement. "I had no choice," she said, volunteering the information that the organization's board had pushed her out [18].

On November 14, 2001, interim CEO and President of the Red Cross, Harold Decker, announced changes adopted by the American Red Cross Board of Governors to meet the immediate and long term needs of people affected by the September 11 terrorist attack. The Red Cross determined it would provide increased financial support to families, participate in a database to be shared among relief agencies, hire an additional 200 case workers, and extend the use of toll-free lines. David T. McLaughlin, chairman of the American Red Cross Board of Governors stated, "The people of this country have given the Red Cross their hard-earned dollars, their trust and very clear direction for our September 11 relief effort. Regrettably, it took us too long to hear their message" [13]. In an article in the U.S. News \& World Report (Nov. 19, 2001), David McLaughlin stated "If we don't subject ourselves to public scrutiny, we will never have public trust".

In addition to donating money, the American public donated blood for the disaster victims. These donations were given in response to then CEO Healy's "Together, we can save a life" public service announcement. Experts questioned the wisdom of calling for blood donations when there were very few blood recipients. By November 2001, about $10 \%$ of the red blood cells collected on September $11^{\text {th }}$ and $12^{\text {th }}$ had expired [18]. In a Congressional hearing, Healy was confronted with allegations of "panicking the public into wasteful donations of blood" [12]. The Lancet reported "Donors charged the organization with abuse of their good intentions".

On March 7, 2002, the American Red Cross saluted the 54,000 staff and volunteers who provided assistance to the more than 54,500 families affected by the attacks. David McLaughlin stated, "Today we are recognizing the work of our staff, volunteers and donors who responded to September $11^{\text {th }} \ldots$.. Harold Decker, interim president and CEO, announced that the American Red Cross received \$930 million in contributions and this money was used to provide: $\$ 169$ million in direct assistance to 3,266 families of the deceased and seriously injured; \$270 million to 51,000 families of displaced workers and disaster workers; and \$94 million was used to provide 14 million meals, mental health services for 232,000 people, and health services for 129,000 people [7].

On February 16, 2002, the Better Business Bureau Wise Giving Alliance removed the American Red Cross from its "give.org" web site allegedly because the American Red Cross did not provide a timely report to the Alliance. In addition, H. Art Taylor, President of the BBB Wise Giving Alliance, made some unsupported public statements regarding the Red Cross that were reported in an article in The Philadelphia Inquirer. A letter from Harold Decker, interim President and CEO of the American Red Cross, to the BBB Wise Giving Alliance explained 
that a request by the BBB Wise Giving Alliance asking for an updated report from the Red Cross was received in January 2002. Given the recent activities of the American Red Cross, it was determined that such a report could not be provided by the due date. In a conversation between Jack Campbell, CFO of the American Red Cross, and Bennett Weiner, COO of the BBB Wise Giving Alliance, the two agreed to a March 30 deadline for the updated report. In his letter Harold Decker requested a public retraction of Mr. Taylor's statements and that the BBB's current report on the Red Cross be restored to the give.org website [5].

In another onslaught of negative publicity, on Sunday, March 10, 2002, the CBS news show 60 Minutes ran a negative report on the American Red Cross. It appears to have contained some inaccuracies and Deborah Daley, a spokesperson for the Red Cross, sent a letter to CBS News indicating the errors and an explanation [13]:

1. In a comment about advertising practices, Mr. Wallace reported "They also decided to put a disclaimer in their ads saying that donations will be used for this and other disasters. The trouble is, it's in small print."

In response, Deborah Daley reported, "In the West Virginia flood ad, the "this and other disaster" language appears in the same font and size as the rest of the body copy appealing to support.

2. Mr. Wallace reported, "Outside audits of local Red Cross chapters are rare. In fact, there is so little accountability that local chapters - and there are more than one thousand of them - aren't even required to submit financial reports to Red Cross headquarters in Washington."

Deborah Daley responded that Chapters are accountable in a number of ways. All chapters must have an independent annual review. Chapters that have over $\$ 100,000$ in annual expenses must have an external audit conducted by an independent CPA. The largest 126 chapters must send quarterly financial reports to the national Red Cross. The Red Cross does regular audits of chapters. Chapters must meet specific national guidelines to maintain their charters. She states that Mr. Wallace's claim that chapters "are not even required to submit financial reports" is completely false.

3. Mr. Wallace reported, "As of last week, 14 months after the fire, San Diego was still waiting for a full accounting of how the money donated for the fire victims has been and will be spent".

Deborah Daley responded that the chapter has provided up-to-date financial information on its response to the Alpine fire three times since November.

\section{Looking To The Future}

After a 5 month search, Marsha 'Marty' Johnson Evans was named Red Cross President and CEO on June 27, 2002. Evans has served as national executive director of the Girl Scouts of the USA for the past four years, and prior to that had a 29-year career in the Navy, where she earned the rank of Rear Admiral. David McLaughlin, chairman of the American Red Cross Board of Governors, said in his announcement, "Marty's unique style of leadership along with her experience as established administrator will bring new vigor to the American Red Cross. With great insight into our mission, she is well poised to guide our organization as we continue to provide vital services in a world faced by new challenges" [9]. Marsha Evans remarked that

"In the midst of responding to the extraordinary demands of 9/11 and a lot of criticism about these efforts, my observation is that the Red Cross never lost sight of its responsibility to every community and every victim of the other disasters that occurred, some 45,000 in the months since last September. The timely and capable response day-in and day-out to these disasters speaks volumes about the character of the volunteers and staff, their talent and most especially their dedication" [9].

As she begins to guide the organization, Marsha Johnson Evans must confront the many issues faced by the American Red Cross. How should she proceed? 


\section{References}

1. $\quad$ American Red Cross Annual Report 2000.

2. $\quad$ American Red Cross Annual Report 2001.

3. American Red Cross web page. www.redcross.org.

4. "American Red Cross and Coinstar to launch new fundraising technology to prepare for disasters". (2001, February 12). US Newswire.

5. “American Red Cross letter to Better Business Bureau's Wise Giving Alliance”. (2002, February 16). PR Newswire.

6. $\quad$ American Red Cross Press Release dated February 1, 2002.

7. $\quad$ American Red Cross Press Release dated March 7, 2002.

8. $\quad$ American Red Cross Press Release dated March 15, 2002.

9. American Red Cross Press Release dated June 27, 2002.

10. "ASAE and American Red Cross formalize partnership agreement". (2001, August). Association Management, v53, i8, p. 12.

11. Becker, Cinda. (2001, October 1). "A torrent of donations; charities wrestle with how best to spend money pouring in since attacks". Modern Healthcare, v31, p. 8.

12. Greenberg, Daniel S., (2001, November 24). Blood, politics, and the American Red Cross, p. 1789.

13. "Red Cross announces major changes in Liberty Fund: Fund solely used for people affected by September 11 tragedy", (2001, November 14). US Newswire.

14. "Newsweek: Former Red Cross head says her fundraising message was clear; Healy asked herself if they were 'Doing it Right' and not if they were 'Controlling the Spin'”, (2001, December 9) PR Newswire.

15. "Red Cross workers on strike", (2000, June). Fund Raising Management, v31, i4, p.33.

16. Sanborn, Stephanie. (2000, June 19). "Nonprofits reap rewards of the Web - Internet proves to e a great fund-raising tool for charities, but there are costs", InfoWorld, v22, i25, p.37.

17. Taylor, Mark. . (2001, January 1). "Red Cross faces antitrust lawsuit", Modern Healthcare, v31, p.20.

18. Tyrangiel, Josh. (2001, November 5). "The Charity Olympics: After weeks of record giving, Americans want to know: Is that money helping?" Time, v158, 820, p. 75.

\section{Figure 1: Principles Of International Red Cross}

- Humanity: The International Red Cross and Red Crescent Movement, born of a desire to bring assistance without discrimination to the wounded on the battlefield, endeavors, in its international \& national capacity, to prevent and alleviate human suffering where it may be found. Its purpose is to protect life and health and to ensure respect for the human being. It promotes mutual understanding, friendship, cooperation and lasting peace amongst all peoples.

- Impartiality: It makes no discrimination as to nationality, race, religious beliefs, class or political opinions. It endeavors to relieve the suffering of individuals, being guided solely by their needs, and to give priority to the most urgent cases of distress.

- Neutrality: In order to continue to enjoy the confidence of all, the Movement may not take sides in hostilities or engage at any time in controversies of a political, racial, religious or ideological nature.

- Independence: The Movement is independent. The National Societies, while auxiliaries in the humanitarian services of their governments and subject to the laws of their respective countries, must always maintain their autonomy so that they may be able at all times to act in accordance with the principles of the Movement.

- Voluntary Service: It is a voluntary relief movement not prompted in any manner by desire for gain.

- Unity: There can be only one Red Cross or one Red Crescent Society in any one country. It must be open to all. It must carry on its humanitarian work throughout its territory.

- Universality: The International Red Cross and Red Crescent Movement, in which all Societies have equal status and share equal responsibilities and duties in helping each other, is worldwide. 
Figure 2: Values of the American Red Cross

* Humanitarianism: We exist to serve others in need, independently, and without discrimination, providing relief for victims of disasters and helping people prevent, prepare for, and respond to emergencies.

* Stewardship: We act responsibly, effectively, and efficiently with resources entrusted to us, always seeking to improve.

* Helping Others: We are attentive and responsive to those we serve, always listening to their needs and looking for ways to serve through existing or new initiatives.

* Respect: We acknowledge, respect, and support the rights and diversity of each person in our organization and in the communities we serve.

* Voluntary Spirit: As a family of donors, volunteers, and staff we search for ways to provide hope to those we serve while demonstrating compassion, generosity, and appreciation.

* Continuous Learning: We seek, collectively and individually, to identify, obtain, and maintain competencies and the awareness required for exceptional service.

* Integrity: We act with honesty, demonstrate courage and accountability under pressure and openly share ideas and information with each other.

\section{Appendix: Teaching Note}

\section{Suggested Courses And Placement Of The Case}

This case may be used in courses such as Strategic Management in undergraduate or graduate Business curriculum as well as in courses dealing with Management of Non-profit Organizations. It should typically be used at two-thirds of the way in the course because the case raises issues of strategic planning, portfolio management, leadership, and leadership challenges in light of all these.

\section{Teaching Suggestions}

1. Discussion questions should be assigned in advance as guidance for students to think about the case. Students who have reached a high level of maturity in strategic thinking may not need such guidance, but a number of students will not be able to see all the issues raised in this teaching note. This is an opportunity for the instructor to help students achieve an "Aha!" experience in discovering the power of conceptual framing of organizational reality.

2. Students may also be assigned the task of researching any other information on American Red Cross through the Internet (http://www.redcross.org). Particularly in the area of financial management, further issues can be explored using some of the more detailed information from American Red Cross's financial statements. For example, the case provides information on Revenue Sources and Operating Expenses. Information on Revenue Sources can be used to discuss the relative share of revenues generated from products and services (66\%) versus from contributions from donors (28\%). Is this an appropriate mix? Typically, a non-profit organization is expected to generate no more than $20 \%$ of its revenues from fees for products and services. Does this situation represent vulnerability for American Red Cross as evidenced by accusations from Hemacare Corp. and Coral Blood Services?

\section{Teaching Objectives}

1. To apply the concepts of strategic management process (such as development of mission/vision statement, goal \& objectives, managing a portfolio of services, implementation of actions) to a non-profit organization. 
2. To examine the importance of mission statement, values and goals, and their connection to the process of managing non-profit organizations.

3. To evaluate the impact of negative publicity on a non-profit organization.

4. To visualize and synthesize strategic action agendas through the application of management principles to non-profit organizations.

5. To assess appropriate leadership traits in a problem-plagued organization.

\section{Suggested Discussion/Assignment Questions}

1. Analyze the mission statement, vision statement, and organizational values of the American Red Cross. How might they be improved?

2. What kind of goals and objectives would you set for an organization such as American Red Cross that deals with disasters, which by their very nature are unpredictable?

3. In selecting alliance partners for organizational endeavors, what organizational traits should executives require?

4. As a newly appointed President and CEO, what should Marsha Johnson Evans do?

\section{Analysis}

1. Analyze the mission and vision statements of the American Red Cross. How might they be improved?

The mission of American Red Cross is succinctly stated in its annual report, as "the American Red Cross is a humanitarian organization, led by volunteers, whose mission is to provide relief to victims of disasters and help people prevent, prepare for, and respond to emergencies". This is a good mission statement as far as the overall thrust of its activities is concerned. In writing a mission statement, it is important to understand the definition of the business [2]: 1) who are its customers, 2) what customer need is the organization trying to fulfill, and 3) how does the business create and deliver value to customers and satisfy their needs. The mission states what it does "provide relief to victims of disasters and help people prevent, prepare for, and respond to emergencies", for whom it performs these activities "victims of disaster, and people who need to prevent, prepare for, and respond to emergencies", and how it approaches its activities - in a "humanitarian" way. There are many other "how's" that might be included in the mission statement. This may include the use of volunteers, strategic alliances, information technology, biomedical services, and training programs. The mission does not mention biomedical services that comprised a major portion of American Red Cross' revenues. While the mission statement covers the clients, some of the activities / services performed, and the philosophy of how it operates, it certainly can be improved.

Have students re-write the American Red Cross' mission statement and attempt to address these shortcomings.

The instructor may raise the question, "how do the fundraising and revenue generating activities of the American Red Cross fall within its mission?" This can generate discussion about whether a mission statement should encompass all of the activities of the organization. Any organization must perform many activities that are needed to support its primary functions that result in its products and services. Do all these activities need to be contained in a mission statement? Do non-profit organizations face vulnerabilities in the way they raise funds? What kinds of fund raising practices have created problems for non-profit organizations? For example, in early 2001, many Police Protective organizations in Colorado came under severe criticism for employing fund raising companies to do the job, when the fund raising companies used questionable practices to approach donors.

The vision statement "The American Red Cross...Always there...touching more lives, in new ways ... under the same trusted symbol" does not provide any clues about the long term direction of the organization [2]. In order to prepare a good vision statement, managers must consider such things as how 
the environment may change in the next 5 years, what new customer needs may have to be satisfied, what new technologies may be introduced that could fundamentally change how the organization operates or affect its services. For example, scientists are working on artificial blood. How would a break through in this arena affect the biomedical services that the American Red Cross provides?

Have students re-write the American Red Cross' vision statement to provide direction about where the organization is going.

2. What goals and objectives would you set for an organization such as American Red Cross that deals with disasters, which by their very nature are unpredictable?

This is a good time to discuss concepts of financial objectives and strategic objectives and the use of short-term and long-term goals/objectives [2].

An organization of this type cannot set goals and objectives with respect to how many disasters or victims it will respond to. They can neither forecast the number of disasters, nor the types of disasters or the number of victims. These are areas of uncertainty

The organization, however, can and should set goals for its various areas of operation where it has some control. For example, American Red Cross can certainly set goals with respect to improving operating efficiencies, the education of people in CPR, number of pints of blood donated by volunteers, number of people taking lifeguard classes, number of youth involved in American Red Cross programs, number of new volunteers recruited, speed of response to disaster victims, readiness to respond to disasters, etc. They should not only keep track of outcomes in these areas, but they can set goals in these areas.

It would be appropriate for the organization to evaluate its capacity utilization. For example, a great deal of blood was donated after September 11, 2001, and much of it needed to be disposed of because it was not used in a timely manner. How can the American Red Cross create a steady supply of blood? Students might consider such ideas as keeping a list of donors and contacting them when blood supplies run low or monitoring blood usage over a period of time to determine average need.

The American Red Cross can also set strategic goals and objectives that reflect how well the organization performs compared to other non-profit agencies that help victims (such as the Salvation Army). Strategic objectives might include being on site or providing services faster than other agencies, offering a wider range of services, etc.

Thus, a non-profit organization of this type will have to delineate various key areas of its operations, examine which of these areas are uncertain and which are open to forecasting, and then set goals for those areas where the organization can see a reasonable amount of certainty.

3. In selecting alliance partners for organizational endeavors, what organizational traits should executives require? What are the benefits of forming strategic alliances?

Strategic alliances in the realm of for-profit businesses are generally defined as "partnerships between potential or actual competitors", to be distinguished from Joint Ventures where the partners may not be actual or potential competitors. Most alliances and joint ventures occur between partners who bring complementary resources to the table in order to exploit opportunities that neither could exploit on their own.

The real question arises as to what kind of partners should American Red Cross aim for companies that have a track record of fulfilling social responsibility, or companies that may not have a track record but are looking to create one? American Red Cross incurs a certain amount of risk in joining hands with companies that may not have a fully espoused and declared philosophy of meeting social 
obligations. For example, what would be the risk if American Red Cross had ever joined hands with a company like Enron only to find out that the executives may have been engaged in unethical practices?

The types of alliances can show nuances of ethical issues. Take the example of ownership of a patent on the protein associated with the underlying cause of Alzheimer's disease. Should such a patent prove profitable, what would be the ethical responsibility of American Red Cross? Should they or should they not allow use of such a "product" free of charge to the public once American Red Cross has recovered the costs of discovering such a protein? Would they be using the gains from victims of Alzheimer's disease to alleviate suffering of some other types of victims?

Even the alliance with Mars is susceptible to some questions. Will the name of American Red Cross allow Mars to sell more candy in the face of increasing number of reports of obesity amongst American people? Is this an ethical issue? Instead of such an alliance, should American Red Cross request Mars to donate money to the cause? Is there a difference between helping promote a certain product versus receiving charitable contribution from a company after it has been able to generate profits from the sale of products that could be considered harmful to the health and well being of the general public?

The above are good follow up questions for class discussion.

There are many benefits to be gained when the American Red Cross forms strategic alliances [2]. For the American Red Cross, the alliances represent opportunities to gain revenues. For the partners of American Red Cross, such as Mars, the alliance represents an opportunity to gain goodwill in the market and to fulfill social obligations. Other benefits that students might consider include: improve the welfare of the public by having more resources available to provide services, reach a wider audience of potential donors, make it easier for the public to donate, increased visibility for the American Red Cross, gain technological expertise, etc.

One may even look at competitive advantages the American Red Cross might gain as a result of forming strategic alliances. For example, the American Red Cross holds patents that have been gained through strategic alliances with medical laboratories, etc. This provides an additional source of revenues that 'competitor' non-profits may not have and may provide additional 'goodwill' with citizens.

4. As a newly appointed President and CEO, what should Marsha Johnson Evans do? How can she restore donors' confidence in the organization? What leadership traits should Marsh Johnson Evans have?

The issues reported in this case show a wide variety of problems and issues for the American Red Cross. A newly appointed CEO must be able to "visualize" the strategic and operational implications of these issues for the organization

The issue regarding disbursement of funds from the Liberty Disaster Relief Fund raises the question of the connection between "perceived restricted donations" versus "restricted or unrestricted donations". Clearly, the American public viewed their donations in response to the September 11 disaster as "restricted" to the victims and helpers of the terrorist attack. Internally, however, there was a debate within American Red Cross about the "drying up" of donations due to the generous response of Americans to the September 11 incident. The decision to use part of the funds for other projects and for long term purposes (in case of other terrorist attacks) represents a "portfolio orientation" towards the various services of American Red Cross.

With respect to this issue, and potential similar issues, American Red Cross will have to clarify, and perhaps revise, their internal policies regarding fund raising tied to specific disasters. Internally, they will have to create an information system that allows them to track donations in response to any fund raising campaign. Externally, they must monitor their advertising practices to clearly communicate to the donors how funds donated in response to an advertisement will be utilized. Should they (or can they) 
clarify this in a 20 second television ad? Can they give the information when the donor contacts Red Cross either through a telephone call, or can they provide this information on a form sent to the donor? They must explore ways to educate the donor so that the donor perceives the full value received from the donation.

This is also a good place to relate this issue to the nature of non-profit organizations. All nonprofit organizations use a "Mediating Technology" within the typologies (Mediating / Long-linked / Intensive) developed by J.D. Thompson [1]. Non-profit organizations mediate between donors / sponsors of funds and the clients / recipients of the non-profit organizations' services. Depending on the service / product line of the non-profit organization, the organization as a whole may create linkages between segments of donors and segments of clients. How can a non-profit organization manage these segmented pools of donors and clients? This could lead to a discussion of portfolio management [2] --- what services should the American Red Cross provide? Are there strategic fits among the services? Are there any services that should be discontinued? Perhaps the American Red Cross should be less involved in offering International Services since there is an International Red Cross to provide these services. Should the American Red Cross discontinue Community services since these types of services do not fit within the scope of the mission statement, which is "to provide relief and assistance to disaster victims"?

The issue of accusations by Hemacare Corp and Coral Blood Services of unfair competitive practices raises a more general issue of non-profit organizations competing with the for-profit sector. The concept of "multi-point competition" can be linked to this issue. Although multi-point competition is a way to put pressure on competitors in the for-profit sector, would it constitute a viable strategy when a nonprofit organization uses it to compete with a for-profit company that may not have a presence in all the different markets? Would this be an issue if the for-profit companies operated in all the different markets where the non-profit organization operates?

The issue of American Red Cross workers in Connecticut going on strike relates to Human Resource Management practices within a non-profit organization. There is a clear trade-off when a nonprofit organization utilizes voluntary workers versus paid workers. The non-profit must devise a conscious compensation strategy when dealing with its paid workers based on the realities of labor markets. Given the use of voluntary workers, a non-profit organization may lose sight of competitive wages in the labor market. Labor contract issues can hurt the image of the non-profit organization in its donor market.

The issue of "outside audits of local Red Cross chapters" relates to monitoring and control of a network of units within Red Cross. The new CEO may want to pursue this issue to bring a sense of transparency to the organization. This issue is particularly significant in light of the accounting and auditing problems in large corporations in the early part of 2002. This issue may be a lead in to development of leadership and management depth within Red Cross. Of course, if the CEO is a controlfreak, she could begin a culture of micro-management - thereby curtailing the autonomy of local chapters.

In an attempt to repair donor confidence Marsha Evans may consider an image building promotional campaign highlighting the good things the American Red Cross has accomplished. Public services announcements might also be useful. Marsha Evans might also consider being a more visible CEO by visiting local chapters and participating in local Red Cross events.

These issues reflect challenges to Red Cross at the corporate (total organization and portfolio of units) level, business (competitiveness of each unit) level, and functional (fund-raising function / information technology / human resource management) level [2]. Prioritization of these issues is necessary. A vision of how American Red Cross will work at all these levels could set the direction for this organization's culture and future activities. This is both a challenge and an opportunity for the new CEO. recommend:

In identifying leadership traits [2] necessary for CEO at the American Red Cross, students might 
- $\quad$ Mediator: The CEO must be able to communicate with volunteers, paid workers, and donors and reconcile any differences the individual might have.

- $\quad$ Empathy: Anticipate needs of victims and ensure the organization can provide needed items or services.

- Motivator: Encourage volunteers into action. In a non-profit organization such as the American Red Cross that relies on the help of volunteers, managers do not have the typical 'stick and carrot' (ability to hire, fire, increase salary) found in for profit businesses. Thus, the CEO needs to motivate and find appropriate rewards for volunteers.

- Know what is happening: Engage in 'Management by Walking Around' activities to understand what is happening at all levels of the organization.

- $\quad$ Spokesperson: The CEO personifies the organization and is the most visible representative of the American Red Cross to the public. The CEO must communicate clearly and often to the stakeholders of the organization.

- Visionary: Be able to look at the macro-picture and set a direction (discussed above).

\section{References}

1. Thompson, J.D. (1967). Organizations in Action. New York: McGraw-Hill.

2. Thompson, J.D. \& Strickland, A.J. (2002). Strategic Management: Concepts \& Cases, New York: McGraw-Hill Irwin.

Notes 
Notes 